\title{
EFFECTS OF DWARF PINE STANDS ON SLOPE DEFORMATION PROCESSES, AS A BASIS FOR THEIR MANAGEMENT IN THE HRUBÝ JESENÍK MOUNTAINS
}

\author{
PAVEL RoŠTÍNSKÝ ${ }^{1}$, MARTIN ŠENFELDR $^{2}$, PETR MADĚRA $^{2}$ \\ 1) Institute of Geonics of the Academy of Sciences of the Czech Republic, v.v.i., \\ Department of Environmental Geography, Drobného 28, 60200 Brno, Czech Republic, e- \\ mail: rostinsky@geonika.cz \\ 2) Mendel University in Brno, Faculty of Forestry and Wood Technology, Department of \\ Forest Botany, Dendrology and Geobiocoenology, Zemědělská 3, 61300 Brno, Czech \\ Republic,e-mail:martinsenfeldr@seznam.cz,petrmad@mendelu.cz
}

Received: $15^{\text {th }}$ February 2013, Accepted: $3^{\text {rd }}$ May 2013

\begin{abstract}
This paper studies non-indigenous dwarf pine stands in the Hrubý Jeseník Mountains, from the perspective of their spatial and genetic relations to slope phenomena of deformation character. The paper contains a typology of regional slope deformations, data on their spatial distribution and specific properties, including risk estimates of their origination or further development in case of potential future dwarf pine stand clearings, as well as a three-stage categorisation of dwarf pine stands based on this tendency. The results were processed using data from literary sources, map documents and aerial photos, as well as an extensive field survey. Three main types of slope deformations were distinguished on sites with highly variable geomorphological features - extensive complex phenomena with numerous subforms, linear debris flows and local shallow landslides. The acquired data show that while dwarf pine stands have no great effect on the development of large slope phenomena, they play a more significant reinforcement role in the prevention of smaller surface deformations, the origination of which is predominantly related to steeper slopes. The results of this study can serve for future decision making on the management of dwarf pine stands.
\end{abstract}

Keywords: non-indigenous dwarf pine, stand categorisation, hazardous slope deformation, management approach, Hrubý Jeseník Mountains, Czech Republic

\section{INTRODUCTION}

The dwarf pine is an alpine shrub appearing mainly in the tree-line ecotone in Central and Eastern Europe (Businský 1998, Hamerník and Musil 2007). These regions along the tree line in European mountain ranges have historically been subjected to human influence. This is also the case of the Hrubý Jeseník Mountains, where pasture, haymaking and logging were performed along the tree-line ecotone from the $17^{\text {th }}$ to the $19^{\text {th }}$ century (Hošek 1973). These anthropogenic effects lead to a considerable lowering of the tree line and, secondarily, to undesirable slope processes and disruption of the water regime (Sokol 
1965). For reasons of stabilisation, intensive afforestation took place there in the past, mainly by spruce and non-indigenous dwarf pine (Hošek 1973).

Recently, there has been a long discussion over the presence of dwarf pine stands in the highest parts of the Hrubý Jeseník Mountains, that are currently protected by the status of the Protected Landscape Area (Treml et al. 2010, Šenfeldr et al. 2012). The nature conservation authority is of the opinion that the historic role of the soil protection by the dwarf pine has finished, and this non-indigenous species now represents hazard rather than an aid to the alpine ecosystems of the Hrubý Jeseník Mountains. This opinion is supported by negative effects of the dwarf pine on phenomena with a close link to forest-free areas (alpine plant species, butterflies, relict patterned ground; Kuras et al. 2001, Treml and Krrížek 2006, Zeidler et al. 2010, 2012). On the other hand, foresters as managers of the dwarf pine stands are fully liable for the stands performing their functions, including e.g. hydrological and soil-protective roles briefly described by Hrádek (2010). To find a reasonable compromise within dwarf pine management between nature conservation and forestry, an analysis of potential geomorphological hazards associated with removing the dwarf pine stands seems to be desirable, as landform elements are significant features under the Jeseník nature protection.

To our knowledge, the research into relationships between dwarf pine stands and geomorphological processes in the Hrubý Jeseník Mountains has mostly concentrated on the evaluation of alpine forest-free area phenomena so far (Treml 2005, Treml and Křížek 2006, 2007, Treml et al. 2007). In particular, micro- and mesoforms, mainly of periglacial origin (patterned ground, earth hummocks) have been studied; however, these are predominantly located in the least inclined parts of slopes in summit areas. The possible hazards listed included the negative effect of the dwarf pine on the depth of frost penetration in the near-surface layer, and a direct pressure of branches on the surface morphology (cf. Sekyra et al. 2002). In contrast, Hrádek (2010) takes the patterned ground for fossil inactive form damaged by pasture and the earth hummocks for phenomena not decisively supported so far. Slope processes on the adjacent steep slopes of mountain valley headwaters have only been explored, with exceptions (Sokol 1965), from this point of view at a more general level, and often using comparison with data from other mountain areas (Treml 2005, Kř́žek 2007b). The significantly related regime of surface and ground water in the transient convex zone of slopes, between gentle summit and steep slope surfaces, was studied by Dalrymple et al. (1968).

The surface of mountain slopes is a result of the antagonistic forces of exogenous and endogenous geomorphological processes. Besides permanent processes, its development is occasionally disrupted by sudden disturbances, sometimes even of a disastrous character, that leave traces in the form of distinctive relief features - slope deformations - changing temporarily, or often permanently, the character of the landscape. The processes of this type can be best captured by studying the spatial distribution and temporal development of the particular sites. The main hazardous deformation phenomena that have been described within the Hrubý Jeseník Mountains studies are debris flows and shallow landslides (Sokol 1965, Gába 1992, Migoń et al. 2002, Treml 2005, Hrádek et al. 2006, Kř́ížek 2007b, Roštínský 2010, 2012). The regional existence of avalanche paths has been considered partially (Treml 2009).

More detailed research into relations of slope phenomena to dwarf pine stands can become a significant additional view of this issue in areas of mountains, and the potential hazards related to the stands reduction or complete removal can thus be minimised. The aims of this study were (1) to create a typology of slope deformations in areas with dwarf pine stands; (2) to ascertain the spatial distribution and significant properties of particular 
types of slope phenomena, including the evaluation of the hazard of their origination and development (activation) in case of potential clearing of dwarf pine stands in contact; (3) to evaluate selected spatial and potential genetic relationships of the dwarf pine to slope deformations generally; and (4) to create a well-arranged categorisation of dwarf pine stands based on their tendency towards dangerous types of slope processes, that could arise in connection with their reduction or clearing.

\section{MATERIALS AND METHODS}

\section{Study area}

The Hrubý Jeseník Mountains (with the highest peak Praděd, $1491 \mathrm{~m}$ a.s.1.) are a mountain range that was formed during the Alpine orogeny on the basement of Hercynian age. The climate is relatively cold and moist with annual precipitation around $1400 \mathrm{~mm}$ and mean ambient temperature of $1.1^{\circ} \mathrm{C}$ in summit areas (Tolasz et al. 2007). The plateaus are characterised by high winter precipitation (snow cover of 100-200 cm) and strong western winds, which blow the snow away from convex surfaces into leeward areas (Jeník 1961). The predominant soil type is podsols. The main ridge forms the European watershed between the Baltic Sea drainage area (the Oder River) and the Black Sea drainage area (the

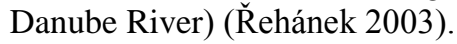

The relief of the main ridge consists of two separate segments in the Keprník Mountains and the Praděd Mountains (Demek et al. 2006) with dwarf pine stands located in the highest parts (Fig. 1). The summit areas with gentle slopes up to $10-15^{\circ}$, dominating surfaces on deluvial sediments and isolated rock formations sharply change into steep slopes of the main mountain valleys with floors up to $700 \mathrm{~m}$ lower, slopes of $20-40^{\circ}$ and frequent firm bedrock outcrops, which are also often proof of the combined forces of fluvial, nivation and glacial processes.

The mountain geology is formed by nappe and faulted structure in the joint of two metamorphosed units of the Silesicum (Opletal 1997, Chlupáč et al. 2002). The Keprník Dome core in the Keprník Mountains (Keprník nappe with remnants of Branná nappes) is dominated by various types of orthogneiss, gneiss, mica schist and phyllite, with a small occurrence of erlan. The Desná Dome in the Praděd Mountains includes rocks of the Desná group - phyllonite, gneiss, metagranitoids - in the dome core and associated paraautochthon in the Vysoká hole nappe near Praděd and younger rocks of the Vrbno group mica schist, phyllite and quartzite - in the dome mantle in the area of Vysoká hole - Pec. Orthogneiss, gneiss, mica schist, phyllite and phyllonite have formed abundant schistosity, especially foliation; their spatial characteristics change based on the place in dependence on intensive deformation of rock complexes. Near the surface, there are frequent dilatation and shear fractures in the bedrock. The disintegration of solid rocks under the sub-aerial conditions on the slopes gave rise to mantles of deluvial sediments several metres thick with numerous bouldery and stony components.

The forest-free areas in peaks are grasslands with dominating graminoids (e.g. Festuca supina, Nardus stricta, Calamagrostis villosa, Calamagrostis arundinacea, Avenella flexuosa) and ericoid shrubs (Vaccinium myrtillus, Vaccinium vitis-idaea). There are also scattered shrubs of juniper (Juniperus communis ssp. alpina). The non-indigenous dwarf pine (Pinus mugo) was planted during the $19^{\text {th }}$ and the $20^{\text {th }}$ centuries with a square spacing of $1.25 \times 1.25 \mathrm{~m}$ to $2 \times 2 \mathrm{~m}$, most abundantly between 1874 and 1928 (Hošek 1973). The dwarf pine currently covers 179.27 ha in the summit areas of the Hrubý Jeseník Mountains, out of which 153.7 ha is located above the alpine timberline (Treml et al. 2010). 
Fig. 1: Main types of slope deformations in the study areas in spatial contacts with dwarf pine stands illustrated in a topographic map (contour lines interval $50 \mathrm{~m}$ ). A - Keprník Mts., B - Praděd Mts. 1 - dwarf pine stand, 2 - complex slope deformation, 3 - snow avalanche path, 4 - debris flow in contact with dwarf pine stand, 5 - another debris flow within complex slope deformation, 6 - shallow landslide, 7 - rock fall, 8 - extensive debris creep. Debris flow sites on Červená hora are marked from the north to the south
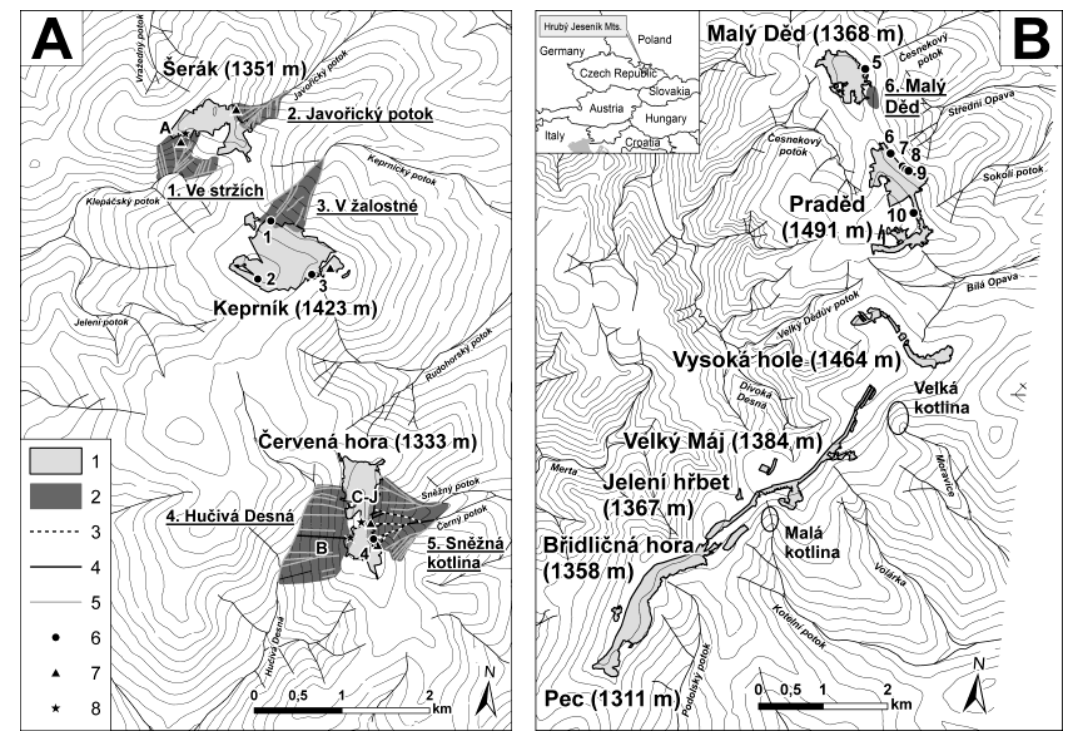

\section{Research design and field data collection}

At the first stage, data on dwarf pine stands and geomorphological processes in the study area with emphasis on information concerning their mutual relations were found (search of literary sources, study of geological and topographic maps, aerial photos) in the context of integrated knowledge on slope phenomena in areas with similar geological composition (typology).

At the second stage, a detailed field geomorphological survey explored the current condition of the identified slope deformations, detected and described other sites in contact with dwarf pine stands and established their possible mutual relations. Besides the actual dwarf pine stands, the explored area included adjacent parts of the Hrubý Jeseník Mountains so that a broader spatial and temporal scale of the examined natural processes could be evaluated generally.

At the final stage, the acquired information was synthesised qualitatively as well as quantitatively, and used for the categorisation of dwarf pine stands based on hazardous geomorphological processes, conducted in GIS. General management recommendations were formulated for particular categories.

\section{Procedure of categorisation of dwarf pine stands with respect to hazardous slope deformations}

The main points of the used categorisation procedure were:

(1) Polygonal delimitation of dwarf pine stands entering the categorisation analysis.

(2) Definition of categorisation degrees based on the level of tendency to undesirable slope processes that would occur in case of dwarf pine clearing.

(3) Definition of hazardous types of slope phenomena. 
(4) Determination of the areal distribution of hazardous phenomena in the spatial contact with dwarf pine stands.

(5) Establishment of the main criteria used for the categorisation and their closer specification.

(6) Segmentation of dwarf pine stands into particular categories.

\section{RESUltS}

\section{Typology of slope deformations}

The regional survey from the perspective of slope deformations was based on their basic types presented in the important studies of this type of abiotic natural phenomena (e.g. Brunsden 1993, Dikau et al. 1996, Nemčok et al. 1974, Záruba and Mencl 1969). However, the classification was modified with respect to the specifics of the study area, the character of the explored issue and the fact that many slope deformations have properties belonging to more described types; their classification is thus more of an informative character. Slope processes are effective in two main spatial dimensions - areal and linear. The smallest phenomena, e.g. fissures, were not considered separately at this stage of study due to their spatially limited effect on dwarf pine stands.

(1) Complex slope deformations. These gravity-conditioned depression phenomena consist of large areas, and are of old origin on the earth's surface; they usually have a character of block landslide areas with a common depth of several tens of metres, affecting not only the superficial deluvial sediments but also their bedrock. Their origination was determined by local geological and topographic conditions - lithology and structure of the bedrock, tectonic fractures and dissected relief. Their identification and location were important as the large older forms, especially in their detachment upper parts, are covered with numerous smaller and younger slope deformations of recent or active character of all below described types, which documents their stronger predisposition effect. That is why the above-mentioned general title was selected for them. Most of the boundaries of these phenomena are obvious in morphology - they are manifested by marked terrain edges. However, some of them could only be defined approximately, based on the occurrence of the other younger types of slope deformations. These also appear independently in the study area, but to a small extent. Complex deformations in the studied area had not been described in a summarizing way before this research.

(2) Debris flows and related phenomena. These are elongated linear deformations that originated as a consequence of a sudden fast flow of mainly loamy-stone deluvial sediments down steep slopes caused by saturation by flush water from precipitation or melted snow. They are often called mures using the original German term meaning high-mountain forms with a similar genesis (Pilous 1973, 1975, 1977). The paths of the flows usually further develop by landsliding in the upper parts, linear water erosion, in some cases also current effects of avalanches, which lead to clearing of transported material and appearance of erosion gullies - with surface water flowing through, which gradually becomes a permanent process. This means a polygenesis of the form by processes that recur in specific periods. The gullies often cut down to the bare bedrock at the bottom, where numerous steps have evolved. Most of the debris flows registered in the study area were described in Sokol (1965), who stated they originated at the end of the $19^{\text {th }}$ and the first half of the $20^{\text {th }}$ century (i.e. a maximum age of 200 years). Since then, many further phenomena have been developed (Gába 1992, Treml 2005, Hrádek et al. 2006, Roštínský 2012), which supports the relatively short time of evolution and proves that these are young forms that used to be 
of singular character in the mountainous landscape of the Hrubý Jeseník Mountains. Only their recent development allowed for the increased accumulation of snow in winter and appearance of avalanches. The period of origination of debris flows in the Hrubý Jeseník Mountains, thus most probably differs from analogical forms in other mountainous areas whose occurrence has been documented at the beginning of the Holocene (e.g. radiocarbon dating of their sediments in the Moravskoslezské Beskydy Mountains; Šilhán 2008).

(3) Shallow landslides. These are usually areal deformations of small extent and of various shapes affecting the turf soil layer that often reach to the upper part of loamy-stone deluvial sediments making them partially exposed. The bedrock is not affected. In comparison with debris flows, they have developed different subforms, mainly broader or more complicated detachment and a preserved accumulation part with a heavily undulating surface. They do not often continue with a gully at the lower edge.

(4) Rock falls. These are processes of gravity-induced free fall of fractions or larger blocks from exposed vertical or precipitous rock walls, and their sedimentation in adjacent talus forms of areal character. They are mainly related to outcrops within complex deformations and debris flows, especially in their detachments, often accompanied by the process of slope toppling. To a small extent they occur on surfaces of isolated summit rock formations (tors), which result from primarily cryogenic processes by frost that were further modelled by other subaerial influences (e.g. Křížek 2007a).

(5) Debris creeps. This concerns an intense areal movement of the upper part of a boulder, stone or loamy-stone weathering product along the slope. It is caused by repeated daily and partially seasonal fluctuations in temperature and moisture, together with an influence of gravitation. With some exceptions (e.g. terracettes representing small step-like landforms; Hrádek 2010), there are no sharp edges on these surface deformations. However, the creep processes affect sediments originating from the other slope processes. They are important for the development of block fields and block streams, specific forms composed of coarse clasts, which are usually the only ones with sharper edges delimiting them in comparison with the surrounding forms. Their increased efficiency there is often dependent on the minimum vegetation cover with a free-forest area, which otherwise protects against the mentioned fluctuations of physical quantities in the near-surface layer. The distribution of debris creeps is of local character; therefore, areas with a dense occurrence of these processes alternate with areas where this process has no considerable manifestations.

\section{Spatial distribution and properties of slope deformations}

This overview considers the sites that are in close contact with dwarf pines.

(1) Complex slope deformations. The area extent and the main properties of complex deformations extending to dwarf pine stand spaces are presented in Fig. 1 and Tables 1, 2, 3. There are 6 cases in total. Five large sites evolved in the Keprník Mountains in the rocks of the Keprník Dome, mainly in the appropriate orthogneiss, mica schist and phyllite. Only a small site Malý Děd has evolved in the Praděd Mountains in the rocks of the Desná Dome, mainly in phyllonites. This indicates the geological predisposition of these phenomena, even with regard to a similar unequal distribution of spatially less extensive types of deformations (debris flows, shallow landslides - see below). For the purposes of categorisation, the mentioned rocks were considered more prone to appearance of hazardous phenomena $\left(1^{\text {st }}\right.$ lithologic type). The other rocks with the minimum current occurrence of these slope forms, located exclusively in the Desná Dome, were categorised to another group ( $2^{\text {nd }}$ lithologic type). 
Table 1: General characteristics of complex slope deformations

\begin{tabular}{|l|cccccc|}
\hline Site & $\begin{array}{c}\text { Length } \\
(\mathbf{m})\end{array}$ & $\begin{array}{c}\text { Width } \\
(\mathbf{m})\end{array}$ & Elevation (m) & $\begin{array}{c}\text { Average } \\
\text { slope }\left({ }^{\circ}\right)\end{array}$ & $\begin{array}{c}\text { Max. slope } \\
\left({ }^{\circ}\right)\end{array}$ & $\begin{array}{c}\text { Bedrock } \\
\text { lithology }\end{array}$ \\
\hline I. Šerák - Ve stržích & 600 & 700 & $1000-1290$ & 30 & 40 & $\begin{array}{c}\text { orthogneiss, mica } \\
\text { schist }\end{array}$ \\
\hline II. Šerák - Javořický potok & 700 & 350 & $1000-1300$ & 27 & 40 & orthogneiss \\
\hline III. Keprník - V žalostné & 1100 & 450 & $970-1335$ & 19 & 25 & mica schist \\
\hline $\begin{array}{l}\text { IV. Červená hora } \\
- \text { Hučivá Desná }\end{array}$ & 850 & 1150 & $880-1325$ & 29 & 35 & $\begin{array}{c}\text { orthogneiss, } \\
\text { erlan, mica schist }\end{array}$ \\
\hline $\begin{array}{l}\text { V. Červená hora } \\
- \text { Sněžná kotlina }\end{array}$ & 1000 & 1000 & $900-1290$ & 22 & 40 & $\begin{array}{c}\text { mica schist, } \\
\text { phyllite }\end{array}$ \\
\hline VI. Malý Děd & 200 & 350 & $1260-1330$ & 18 & 20 & $\begin{array}{c}\text { metaarcose, } \\
\text { phyllonite }\end{array}$ \\
\hline
\end{tabular}

Maximal slope represents the highest value of surface inclination in a detachment area of the site out of rock outcrops.

Table 2: Selected additional characteristics of complex slope deformations

\begin{tabular}{|c|c|c|c|}
\hline Site & Bedrock structure & $\begin{array}{l}\text { Current geomorphological } \\
\text { activity }\end{array}$ & $\begin{array}{l}\text { Geomorphological location of } \\
\text { dwarf pine stands }\end{array}$ \\
\hline I. & $\begin{array}{l}\text { Keprník Dome; upper part } \\
\text { folded orthogneiss with } \\
\text { foliation dip } \sim 30^{\circ} \text { into the } \\
\text { slope, lower part mica schist } \\
\text { locally foliated along the } \\
\text { surface }\end{array}$ & $\begin{array}{l}\text { slope toppling, rock falling, } \\
\text { fissure systems in gully heads and } \\
\text { shallow landslides exposing } \\
\text { deluvial deposits, recent debris } \\
\text { flowing, intensive debris creeping }\end{array}$ & $\begin{array}{l}\text { transient zone between gentle } \\
\text { summit surface }\left(7^{\circ}\right) \text { and steep } \\
\text { slope of valley head in the } \\
\text { detachment area }\left(40^{\circ}\right)\end{array}$ \\
\hline II. & $\begin{array}{l}\text { Keprník Dome; folded } \\
\text { orthogneiss with foliation dip } \\
\sim 10^{\circ} \text { into the slope }\end{array}$ & $\begin{array}{l}\text { rock falling, intensive debris } \\
\text { creeping }\end{array}$ & $\begin{array}{l}\text { transient zone between gentle } \\
\text { summit surface }\left(10^{\circ}\right) \text { and steep } \\
\text { slope of amphitheatre valley head } \\
\text { in the detachment area }\left(40^{\circ}\right)\end{array}$ \\
\hline III. & $\begin{array}{l}\text { Keprník Dome; upper part } \\
\text { orthogneiss, middle and lower } \\
\text { parts mica schist }\end{array}$ & $\begin{array}{l}\text { fissure systems in gully heads and } \\
\text { small landslides exposing deluvial } \\
\text { deposits, short gully reaches with } \\
\text { numerous cut banks, recent } \\
\text { shallow landsliding }\end{array}$ & $\begin{array}{l}\text { transient zone between gentler } \\
\text { summit surface }\left(10-15^{\circ}\right) \text { and } \\
\text { steeper slope of valley head in the } \\
\text { detachment area }\left(20-25^{\circ}\right)\end{array}$ \\
\hline IV. & $\begin{array}{l}\text { Keprník Dome; upper part } \\
\text { orthogneiss, middle and lower } \\
\text { parts mica schist }\end{array}$ & $\begin{array}{l}\text { recent shallow landsiding, rock } \\
\text { falling, intensive debris creeping }\end{array}$ & $\begin{array}{l}\text { transient zone between gentler } \\
\text { summit surface }\left(20^{\circ}\right) \text { and steeper } \\
\text { valley slope in the detachment area } \\
\left(25-35^{\circ}\right)\end{array}$ \\
\hline V. & $\begin{array}{l}\text { Keprník Dome; upper part } \\
\text { folded orthogneiss with } \\
\text { foliation dip } \sim 30^{\circ} \text { into the } \\
\text { slope, middle and lower parts } \\
\text { mica schist and phyllite, } \\
\text { locally foliated along the } \\
\text { surface }\end{array}$ & $\begin{array}{l}\text { slope toppling, rock falling, } \\
\text { fissure systems in large landslide } \\
\text { and gully heads exposing deluvial } \\
\text { sediments, avalanche movement } \\
\text { of the snow eroding bedrock, } \\
\text { recent debris flowing, intensive } \\
\text { debris creeping }\end{array}$ & $\begin{array}{l}\text { transient zone between gentler } \\
\text { summit surface }\left(15^{\circ}\right) \text { and steep } \\
\text { slopes of two amphitheatre valley } \\
\text { heads in the detachment area ( } 30- \\
\left.40^{\circ}\right)\end{array}$ \\
\hline VI. & Desná Dome; folded phyllonite & $\begin{array}{l}\text { fissure systems in detachment } \\
\text { area exposing deluvial deposits }\end{array}$ & $\begin{array}{l}\text { transient zone between gentler } \\
\text { summit surface }\left(10^{\circ}\right) \text { and steeper } \\
\text { slope of valley head in the } \\
\text { detachment area }\left(15-20^{\circ}\right)\end{array}$ \\
\hline
\end{tabular}


Table 3: Detailed geomorphological features of complex slope deformations

\begin{tabular}{|c|c|c|c|}
\hline Site & Upper part & Middle part & Lower part \\
\hline I. & $\begin{array}{l}\text { WSW-ENE trending } \\
\text { topographic scarp with } \\
\text { several steps, rare rock forms } \\
\text { up to } 10 \mathrm{~m} \text { high, block field, } \\
\text { small debris flow }\end{array}$ & $\begin{array}{l}\text { rock walls a few tens of metres } \\
\text { high, isolated rock blocks, block } \\
\text { fields and streams, } \sim 15 \text { debris } \\
\text { flow paths of gully character } \\
\text { sporadically cut down the } \\
\text { bedrock, a few stream-like } \\
\text { shallow landslides }\end{array}$ & $\begin{array}{l}60 \mathrm{~m} \text { wide and more than } 3 \mathrm{~m} \\
\text { thick boulder-like sedimentary fill } \\
\text { of the valley floor with permanent } \\
\text { stream }\end{array}$ \\
\hline II. & $\begin{array}{l}\text { NNW-SSE trending } \\
\text { topographic scarp, rock walls } \\
\text { a few of metres high, two } \\
\text { avalanche paths }\end{array}$ & $\begin{array}{l}\text { large landslide accumulation } \\
\text { with heavily undulating surface, } \\
\text { block stream, small rock forms }\end{array}$ & $\begin{array}{l}\sim 12 \text { debris flow paths of } \\
\text { interconnecting gullies character, } \\
\text { some with permanent streams }\end{array}$ \\
\hline III. & $\begin{array}{l}\text { less distinctive topographic } \\
\text { scarp of NW-SE trend, } \\
\text { several small landslides with } \\
\text { accumulations with heavily } \\
\text { undulating surfaces and } \\
\text { ephemeral pools }\end{array}$ & $\begin{array}{l}\text { two debris flow paths, shallow } \\
\text { gullies }\end{array}$ & $\begin{array}{l}\text { interconnecting deep gullies } \\
\text { sporadically cut down the } \\
\text { bedrock, some with permanent } \\
\text { streams }\end{array}$ \\
\hline IV. & $\begin{array}{l}\text { NNE-SSW trending } \\
\text { topographic scarp, two deep- } \\
\text { seated landslides in heads of } \\
\text { largest debris flows with } \\
\text { accumulations with heavily } \\
\text { undulating surfaces, small } \\
\text { rock outcrops, small block } \\
\text { streams, recent shallow } \\
\text { landslide }\end{array}$ & $\begin{array}{l}\text { small N-S trending topographic } \\
\text { steps, } \sim 10 \text { debris flow paths of } \\
\text { gully character with scarce } \\
\text { springs, dispersed boulders }\end{array}$ & $\begin{array}{l}\text { main permanent stream channel } \\
\text { considerably cut down the } \\
\text { bedrock by deep erosion }\end{array}$ \\
\hline V. & $\begin{array}{l}\mathrm{N}-\mathrm{S} \text { trending topographic } \\
\text { scarp, rock wall more than } 5 \\
\mathrm{~m} \text { high and } 100 \text { m wide, } \\
\text { deep-seated landslide with } \\
\text { bedrock outcrops and heavily } \\
\text { undulating surface in } \\
\text { detachment amphitheatre in } \\
\text { the head of largest debris } \\
\text { flow, initial parts of other } \\
\text { debris flow paths (total } ~ 20) \text {, } \\
\text { partly utilised as avalanche } \\
\text { paths ( } 5 \text { cases), smaller rock } \\
\text { outcrops under large rock } \\
\text { forms and in heads of debris } \\
\text { flow paths, shallow } \\
\text { landslides, dispersed } \\
\text { boulders }\end{array}$ & $\begin{array}{l}\text { bedrock outcrops and large } \\
\text { isolated blocks up to several } \\
\text { metres high, deepening debris } \\
\text { flow paths of an interconnecting } \\
\text { gullies character sporadically cut } \\
\text { down the bedrock, shallow } \\
\text { landslides, dispersed boulders }\end{array}$ & $\begin{array}{l}\text { three distinctive } \mathrm{V} \text {-shaped valleys } \\
\text { with permanent streams }\end{array}$ \\
\hline VI. & $\begin{array}{l}\text { shallow depression with less } \\
\text { distinctive NNE-SSW } \\
\text { trending topographic scarp }\end{array}$ & $\begin{array}{l}\text { undulating surface with } \\
\text { dispersed boulders }\end{array}$ & $\begin{array}{l}\text { no distinctive geomorphological } \\
\text { features }\end{array}$ \\
\hline
\end{tabular}


(2) Debris flows and avalanche paths. Debris flows, usually transformed into erosion cuts, were registered at 10 places (Fig. 1, Table 4), always within a framework of a complex deformation. Except the small form in the detachment of Šerák - Ve stržích and the upper part of a debris flow on the western slope of Červená hora in the Hučivá Desná River valley, all of them are located on the eastern slope of Červená hora in headwater areas of the cirque of Sněžná kotlina, where an avalanche movement of snow was also recorded in the lines of five of them (Treml 2009).

Table 4: General characteristics of debris flow paths

\begin{tabular}{|c|c|c|c|c|c|c|}
\hline Site & \begin{tabular}{|c|} 
Length \\
(m)
\end{tabular} & $\begin{array}{c}\text { Max. } \\
\text { width (m) }\end{array}$ & $\begin{array}{l}\text { Elevation } \\
\quad(\mathbf{m})\end{array}$ & $\begin{array}{c}\text { Avg. (max.) } \\
\text { slope ( }\left(^{\circ}\right)\end{array}$ & $\begin{array}{c}\text { Bedrock } \\
\text { lithology }\end{array}$ & Comment \\
\hline $\begin{array}{l}\text { A. Šerák } \\
- \text { Ve stržích }\end{array}$ & 30 & 5 & $1265-1280$ & $31(33)$ & orthogneiss & recent occurrence \\
\hline $\begin{array}{l}\text { B. Červená hora } \\
\text { - Hučivá Desná }\end{array}$ & 730 & 50 & $965-1315$ & $29(32)$ & $\begin{array}{r}\text { orthogneiss, } \\
\text { mica schist }\end{array}$ & head with landslide \\
\hline $\begin{array}{l}\text { C. Červená hora } \\
- \text { Sněžná kotlina } 1\end{array}$ & 750 & 100 & $930-1270$ & $27(32)$ & $\begin{array}{l}\text { mica schist, } \\
\text { phyllite }\end{array}$ & $\begin{array}{c}\text { head with landslide, } \\
\text { avalanche path in } \\
\text { middle and lower } \\
\text { part }\end{array}$ \\
\hline $\begin{array}{l}\text { D. Červená hora } \\
\text { - Sněžná kotlina } 2\end{array}$ & 130 & 5 & $1200-1270$ & $32(33)$ & $\begin{array}{c}\text { mica schist, } \\
\text { phyllite }\end{array}$ & $\begin{array}{l}\text { floor with planted } \\
\text { dwarf pine stands }\end{array}$ \\
\hline $\begin{array}{l}\text { E. Červená hora } \\
\text { - Sněžná kotlina } 3\end{array}$ & 210 & 10 & $1160-1270$ & $31(32)$ & $\begin{array}{l}\text { mica schist, } \\
\text { phyllite }\end{array}$ & \\
\hline $\begin{array}{l}\text { F. Červená hora } \\
\text { - Sněžná kotlina } 4\end{array}$ & 450 & 15 & $1030-1265$ & $31(34)$ & $\begin{array}{c}\text { mica schist, } \\
\text { phyllite }\end{array}$ & $\begin{array}{c}\text { rocky head, } \\
\text { avalanche path }\end{array}$ \\
\hline $\begin{array}{l}\text { G. Červená hora } \\
\text { - Sněžná kotlina } 5\end{array}$ & 190 & 10 & $1170-1265$ & $29(35)$ & $\begin{array}{c}\text { mica schist, } \\
\text { phyllite }\end{array}$ & \\
\hline $\begin{array}{l}\text { H. Červená hora } \\
\text { - Sněžná kotlina } 6\end{array}$ & 860 & 20 & $895-1260$ & $25(39)$ & $\begin{array}{l}\text { mica schist, } \\
\text { phyllite }\end{array}$ & $\begin{array}{l}\text { recent shallow } \\
\text { landslide on the } \\
\text { floor, snow } \\
\text { avalanche trace }\end{array}$ \\
\hline $\begin{array}{l}\text { I. Červená hora } \\
\text { - Sněžná kotlina } 7\end{array}$ & 180 & 10 & $1160-1260$ & $33(37)$ & $\begin{array}{l}\text { orthogneiss, } \\
\text { mica schist, } \\
\text { phyllite }\end{array}$ & $\begin{array}{l}\text { recently removed } \\
\text { dwarf pine stands, } \\
\text { avalanche path }\end{array}$ \\
\hline $\begin{array}{l}\text { J. Červená hora } \\
\text { - Sněžná kotlina } 8\end{array}$ & 200 & 10 & $1130-1245$ & $35(37)$ & $\begin{array}{l}\text { orthogneiss, } \\
\text { mica schist, } \\
\text { phyllite }\end{array}$ & $\begin{array}{l}\text { rocky head, } \\
\text { avalanche path }\end{array}$ \\
\hline
\end{tabular}

(3) Shallow landslides. The phenomena of small extent found within the shallow landslide type (Fig. 1,2) are characterised in Table 5. In total, 10 cases are registered. Two of them are located on Keprník (V žalostné) and Červená hora (Sněžná kotlina) in the areas of complex deformations, the remaining eight are located separately in relatively intact slopes. 
Fig. 2: Example of small superficial soil cover detachment, induced by a shallow planar landslide on the site of Vegetační chodník on the NE slope of Praděd. The upper boundary of the damaged area is determined by a straight-lined lower margin of the dwarf pine stand with evident protective function

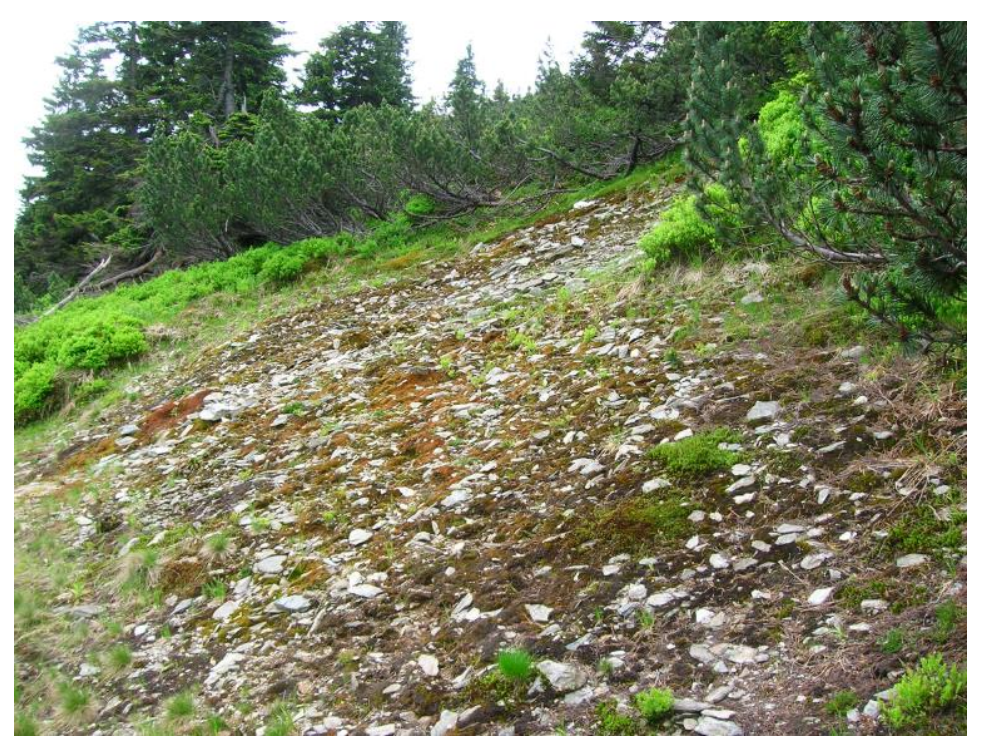

Table 5: General characteristics of active shallow landslides

\begin{tabular}{|c|c|c|c|c|c|c|}
\hline Site & $\begin{array}{c}\text { Length } \\
\text { (m) }\end{array}$ & $\begin{array}{c}\text { Width } \\
\text { (m) }\end{array}$ & $\begin{array}{l}\text { Elevation } \\
\text { (m) }\end{array}$ & $\begin{array}{l}\text { Average } \\
\text { slope }\left(^{\circ}\right)\end{array}$ & $\begin{array}{l}\text { Bedrock } \\
\text { lithology }\end{array}$ & $\begin{array}{c}\text { Spatial relation } \\
\text { to dwarf pine } \\
\text { stands } \\
\end{array}$ \\
\hline 1. Keprník - V žalostné & 80 & 30 & $1280-1310$ & 23 & mica schist & under stand \\
\hline $\begin{array}{l}\text { 2. Keprník - vrcholový } \\
\text { stupeň }\end{array}$ & 15 & 10 & $1395-1400$ & 18 & orthogneiss & between stands \\
\hline $\begin{array}{l}\text { 3. Keprník - sedlo } \\
\text { Malý Keprník }\end{array}$ & 20 & 10 & $1330-1335$ & 15 & $\begin{array}{l}\text { orthogneiss, } \\
\text { metagranite }\end{array}$ & between stands \\
\hline $\begin{array}{l}\text { 4. Červená hora - } \\
\text { Sněžná kotlina }\end{array}$ & 20 & 10 & $1240-1250$ & 33 & $\begin{array}{c}\text { mica schist, } \\
\text { phyllite }\end{array}$ & under stand \\
\hline $\begin{array}{l}\text { 5. Malý Děd - } \\
\text { východní svah * }\end{array}$ & 20 & 10 & $1340-1345$ & 12 & $\begin{array}{c}\text { mica schist, } \\
\text { phyllite }\end{array}$ & between stands \\
\hline $\begin{array}{l}\text { 6. Praděd - Vegetační } \\
\text { chodník } 1\end{array}$ & 15 & 10 & $1305-1310$ & 22 & phyllonite & under stand \\
\hline $\begin{array}{l}\text { 7. Praděd - Vegetační } \\
\text { chodník } 2\end{array}$ & 15 & 10 & $1300-1305$ & 28 & phyllonite & under stand \\
\hline $\begin{array}{l}\text { 8. Praděd - Vegetační } \\
\text { chodník } 3\end{array}$ & 30 & 10 & $1295-1310$ & 28 & phyllonite & under stand \\
\hline $\begin{array}{l}\text { 9. Praděd - Vegetační } \\
\text { chodník } 4\end{array}$ & 30 & 30 & $1295-1310$ & 27 & phyllonite & under stand \\
\hline $\begin{array}{l}\text { 10. Praděd - Sokolí } \\
\text { potok }\end{array}$ & 10 & 10 & $1400-1405$ & 25 & phyllonite & between stands \\
\hline
\end{tabular}

Asterisk (*) indicates the sole site with a permanent spring. 
(4) Rock falls. The sites of rock falls in a direct spatial contact with dwarf pine stands are limited in numbers. Five sites were registered (Fig. 1) with a height of rock walls up to 10 $\mathrm{m}$. They occur within complex deformations in the detachment scarp of Šerák - Ve stržích, there is a low rock wall in the detachment scarp of Šerák - Javořický potok, and two rock debris flow detachments utilised by avalanches in the headwater area of Černý potok in Sněžná kotlina. Isolated rock formations in this position are summit outcrops of Malý Keprník (eastern peak of Mt. Keprník).

(5) Extensive debris creeps. Extensive debris creeps of coarse clastic varieties (block fields, block streams) within spaces of dwarf pine stands are also scarce. We found three more significant areas (Fig. 1). The largest one is located above the detachment scarp of the complex deformation Šerák - Ve stržích (height range of several tens of metres, $100 \mathrm{~m}$ long, $200 \mathrm{~m}$ wide). Smaller examples are located on Červená hora in the amphitheatre detachment of the largest debris flow in the Hučivá Desná River valley, and under a large rock formation on the mountain summit directed towards Sněžná kotlina.

The research has shown that out of the five defined types, mainly three pose a serious hazard related to clearing of dwarf pine stands - the complex deformations with numerous subforms in the detachments, the debris flows and the shallow landslides. On these sites, there are many typical features contributing to the current activity of hazardous slope processes. Slope deformations are considered active forms of the surface according to methodology Rybář (1999) and Rybář et al. (1999), taking into account mainly marked, sharply shaped partial forms of landslides located usually in their upper parts, such as detachment scarps with fresh fissures exposing deluvial sediments, small erosion gullies with numerous cut banks or recent shallow landslides. The other identified sites are referred to as potential slope deformations.

\section{Selected spatial and genetic relations of dwarf pine stands to slope deformations}

Dwarf pine stands are located at altitudes of 1200-1480 m. They were planted regardless of the lithologic composition of the bedrock. They are situated in very variable positions in relation to the underlying landforms with superficial slopes of $0-45^{\circ}$. The majority of their areas - nearly $80 \%$ - are located in flat and gently sloping summit surfaces (slopes up to $15^{\circ}$ ), which are little prone to slope deformations. Only the remaining $20 \%$ are located in upper steeper parts of slopes or valley headwaters. From the perspective of spatial relations to complex deformations, dwarf pine stands only appear in their steepest uppermost segments. A similar position was found in the case of debris flows. The sites of shallow landslides are most often located at the lower line of dwarf pine stands ( 5 cases), at their side edges ( 2 cases), and in 3 cases they are completely surrounded by them.

The related extent of dwarf pine stands density in the study area is variable, from the predominance of closed canopy stands to the mosaic cover, with numerous enclaves of spruce or grassland, to isolated scattered cover with few individuals. No damaged dwarf pine stands or their root systems were registered at the places of currently active slope deformations, because all these sites were located within a vegetation cover of another species (trees, grass). Surface deformations found at the places directly below dwarf pines within the entire area were only slight and had a form of small fissures. From the perspective of the type of spatial distribution of groups of dwarf pine individuals, the predominant layout is isometric; only to a small extent the dwarf pines were planted in zonal arrangement with the predominant direction along the slope.

The analysis of the substrate in dwarf pine stands, from the perspective of its reinforcement or damage by the root system or branches, resulted in the classification into three basic types: 
(1) The dwarf pine appears directly on the bedrock sporadically - sites of the rock tor in Malý Keprník, valley headwater of Javořický potok on Šerák and detachment areas of several debris flows in Sněžná kotlina on Červená hora. Roots of several vital young specimens on Malý Keprník grow into the subhorizontal clefts of foliated orthogneiss, which in the future after they grow stronger will lead to a partial laminar disintegration of the rock formation. Roots at one place on Červená hora reinforce the surface above a rock recess edge at the beginning of a debris flow, with a gully directed as its continuation and they most probably also partially interfere with vertical clefts in the bedrock. The roots thus slow down further deepening of the gully into the bedrock in upper parts of the slope (cf. Hrádek 2010).

(2) More frequently, there are dwarf pines on boulder debris - the upper part of sites Ve stržích and to a small extent also Javořický potok on Šerák. The undulating surface of debris is characterised by a number of partial elevations and depressions. Moreover, there are large free spaces among the boulders. The dwarf pine has to adhere to the bedrock base by roots often vertically lead, and thus a deeper reach of its root system is assumed. Besides the reinforcement function of the roots, the movement of boulders in the superficial part of the debris downwards along the slope is slowed down by lower parts of branches of the dwarf pine stands.

(3) The majority of dwarf pine stands grow on loamy-stone substrate representing the most frequent type of deluvial sediments in the area. On these sites, subhorizontal orientation of roots predominates; the roots are network-arranged and lower plagiotropic parts of main branches grow from them parallel to the surface. This indicates the generally shallow reach of the contact of dwarf pine cormons with the substrate. It was found that the root system is usually limited by the lithologic boundary between a thin upper fine-grained soil layer and the stony base.

Forestry interventions in the area of Sněžná kotlina on Červená hora were performed with the aim to slow down the development of the debris flows: dense stands of the dwarf pine were planted at the bottoms of flows reaching low to the forest area (similar but smaller in the valley headwater of Javořický potok) as well as on less damaged intervening surfaces of a complex deformation and more gently sloping summit positions above its upper limit. While no significant recent deformations were found on the intervening slopes, a number of new forms were detected in the mentioned linear depressions of debris flows, e.g. exposed rocky bottoms of gullies, shallow landslides, rock falls from exposed walls and fresh fissures in the surface.

\section{Categorisation of dwarf pine stands with respect to hazardous slope processes}

(1) The plots of dwarf pine stands were constructed by creating outlines of raster data of dwarf pine delimitation published by Tippner (2012).

(2) Three degrees of categorisation were established with a decreasing relative level of hazard in case of stand clearings: 3 - high hazard, 2 - middle hazard, 1 - low hazard.

(3) Recent and mainly current slope processes with manifestations of partial or complete activity in the current topography in the form of deformation effects were determined to be hazardous. These often occur within extensive recent forms. They comprise complex deformations with a number of partial young morphological elements, especially in upper detachment and central parts - debris flows, gullies, shallow landslides - and additional shallow landslides in independent positions. They represent current risks in the form of possible further damage of slope surfaces and stands on them.

(4) Six complex deformations and eight independent shallow landslides were defined in a spatial contact with dwarf pine stands. 
(5) The determining categorisation criterion was established as the direct occurrence of dwarf pine stands in the space or immediate vicinity of hazardous slope deformations. In the context of possible further development of the sites in the near future, they were assigned with a protective zone for the purposes of consequent analysis. Its size was specified with respect to the maximum spatial dimension of the found active slope phenomena or their parts within the study area as a whole, as well as with respect to the type of site, as follows: (i) up to $100 \mathrm{~m}$ in the ground plan for complex deformations with newly activated parts, mainly detachments; (ii) up to $50 \mathrm{~m}$ in the ground plan for complex deformations without newly activated parts; (iii) $50 \mathrm{~m}$ in all directions in the ground plan from the centre of sites of independent shallow landslides. Regarding complex deformations, the width of the protective zone gradually decreases in the direction from the detachment, where the risk of site expansion by further movement is the highest, along the slope towards the valley until it reaches zero at the place of the process end at the valley bottom, where the hazard is minimal.

Based on the above-mentioned research results, the second criterion of the main geomorphological factors was established to be the inclination of the terrain with the limit value dependent on the type of bedrock. The lower critical limits of slope inclination for the origination of slope deformations were chosen to be $15^{\circ}$ and $18^{\circ}$ for areas of the $1^{\text {st }}$ and $2^{\text {nd }}$ lithologic types, respectively. An analogical procedure was utilised for the evaluation of territorial tendency to slope deformations in the Outer Western Carpathians (Rybár 1999, Rybár et al. 1999). The study area was consequently divided into parts with subcritical and supercritical slope inclinations (Fig. 3).

Fig. 3: Schematic distribution of super- and subcritically inclined surfaces in the study areas. A - Keprník Mts., B - Praděd Mts. 1 - dwarf pine stand, 2 - phyllonite occurrence (Desná Dome of the Silesicum), 3 - supercritical slope inclination $\left(>15^{\circ}\right.$ or $18^{\circ}$, respectively), $4-$ subcritical slope inclination $\left(<15^{\circ}\right.$ or $18^{\circ}$, respectively)
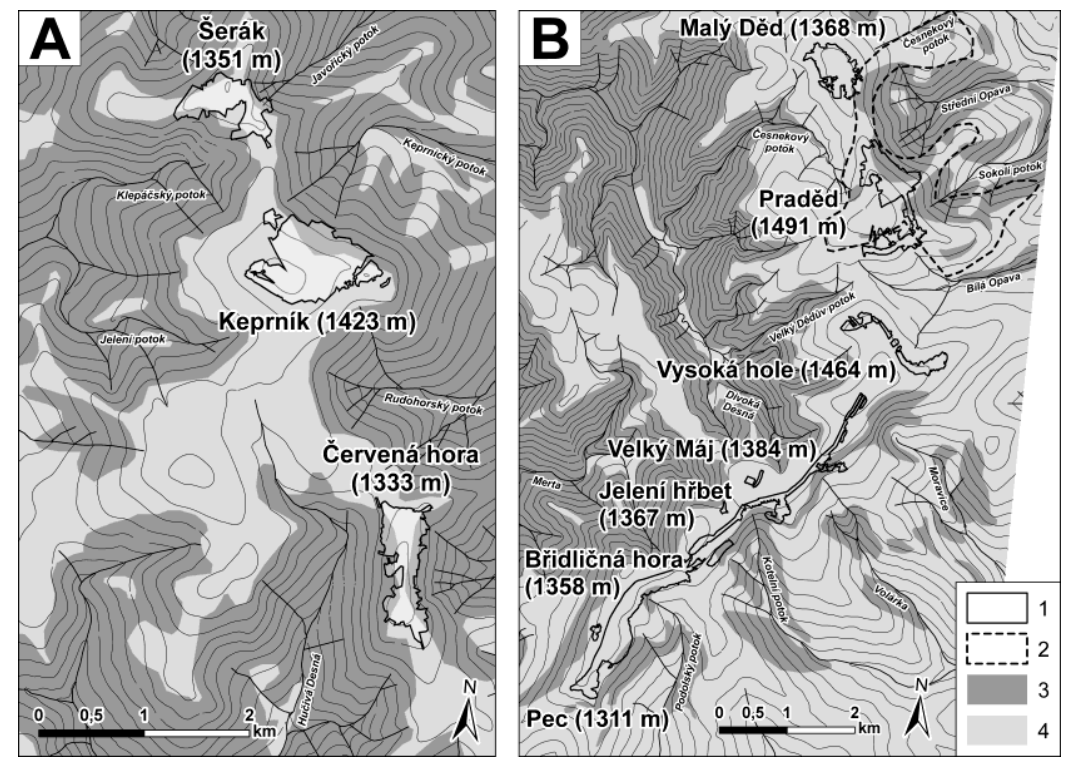

An auxiliary criterion was the size of the area and the extent of dwarf pine stands canopy in the limited hazard area. Small areas with dimensions of several tens of metres, or areas 
with unclosed canopy stands, were not considered independently and the segment was left in the prevailing adjacent category.

(6) The dwarf pine stands were assorted in the categories with respect to their reach into the space of slope deformations, including protective zones or their occurrence in areas with supercritical slopes in the following way (Fig. 4).

Category 3: The entire sites of complex deformations, with manifestations of current movement activity and areas of numerous independent shallow landslides, which are located in close mutual vicinity.

Category 2: The entire sites of complex deformations without manifestations of current movement activity, sites with supercritical inclination outside sites of complex deformations and sites with subcritical inclination at places of independent shallow landslides, with the above-mentioned exception of accumulation.

Category 1: Sites with subcritical inclination outside sites of complex deformations and independent shallow landslides.

The analysis of the spatial distribution of the particular categories of dwarf pine stands shows that the category with the highest hazard - category 3 (12\% of the entire area) appears in the upper parts of south-western and north-eastern slope of Šerák, the northeastern slope of Keprník, a prevailing part of the summit of Červená hora, and in small enclaves on the north-eastern slope of Praděd. The central category $2(13 \%)$ contains the remaining steep slopes of Šerák, Keprník, Červená hora, most of the north-eastern slope of Praděd, and small enclaves in upper parts of south-eastern slopes of Velký Máj, Jelení hřbet and Břidličná hora. The stands in the category with smallest hazard, category 1 (75\%), are mainly located in summit areas of most peaks (Fig. 4).

Fig. 4: Final three-stage categorisation of dwarf pine stands with respect to a spatial tendency to hazardous slope processes in case of their prospective clearing. A Keprník Mts., B - Praděd Mts. Category 3 - high hazard, Category 2 - middle hazard, Category 1 - low hazard
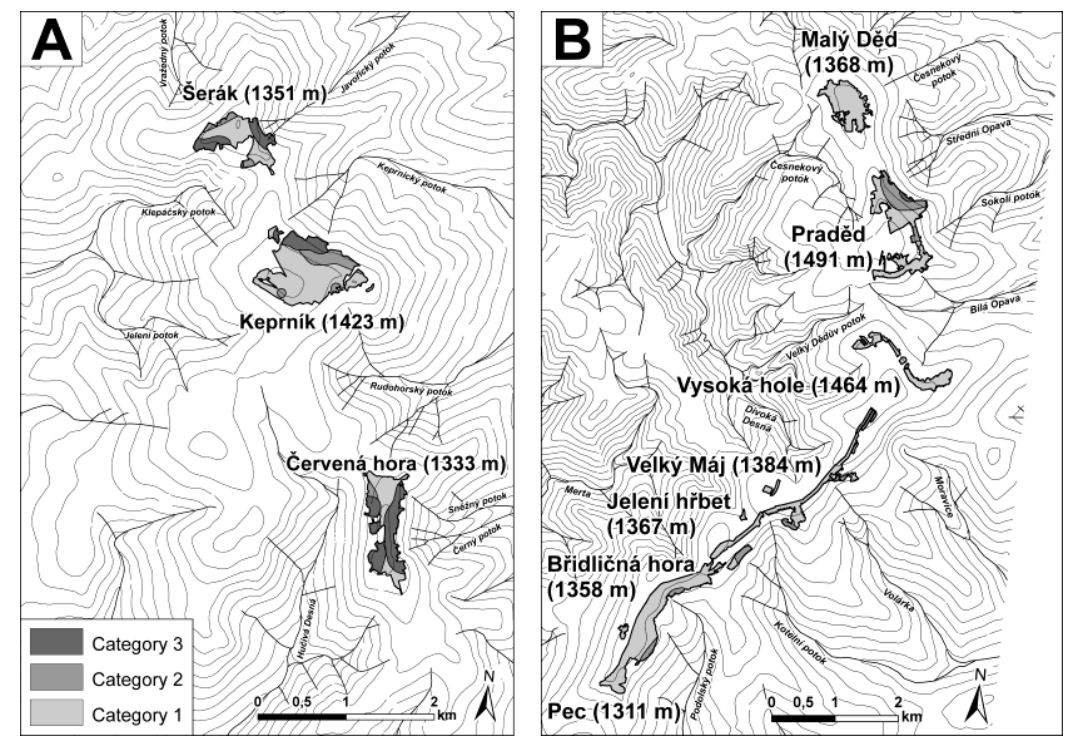


\section{DISCUSSION}

\section{Abiotic properties of slope deformations}

The necessity of biological remediation of mountain slopes of the Hrubý Jeseník Mountains, regarding the development of hazardous superficial abiotic processes, has been pointed out by Sokol (1965), Hošek (1973) and Horák (1977). This presented summarising analysis of the explored detailed characteristics of slope deformations provides us with additional generalising knowledge. The most significant geomorphological factor for the evolution of dangerous slope deformations is clearly the slope inclination, which reaches $15-35^{\circ}$ on most sites, exceptionally even $40^{\circ}$, but most often $20-25^{\circ}$. A similar result has been arrived at by Sokol (1965), Treml (2005) and Křížek (2007b).

Complex deformations have occurred mostly in valley headwaters with the steepest slopes, induced by a long-term effect of nivation processes during the Quaternary (cf. Opletal 1997). Movements were often facilitated by the presence of favourable structural conditions (rocks with a high proportion of cleavable minerals, arrangement of foliation planes along the slope inclination, local existence of cleft systems in detachment areas along lithologic boundaries). Mainly the presence of mica with abundant divisional planes provides conditions for specific geotechnical properties (easier seepage of water decreasing viscosity, considerable increase in volume by bound water) that lead to fast weathering, mushing and thus damage of relevant rocks (mica schist, phyllite) and evolution of a mighty cover of weathering products and deluvial sediments of mainly laminar character (Zvejška 1947, later specified by Hrádek and Lacina 2003). On the other hand, a significant effect of permanent saturation of near-surface layers of the rock massif was not observed in the study area.

Besides primary climatic and hydrological factors (Sokol 1965, Gába 1992), the debris flows were conditioned by local lithologic properties with the dominance of rocks with a high content of mushable mica minerals (predominantly mica schist and phyllite; Hrádek et al. 2006) and especially the great inclination of the slope $\left(25-40^{\circ}\right)$. Permanent springs of ground water in their heads were not found, which confirms that they are phenomena induced by a combined activity of surface and sub-surface flow during sudden hydrological events (cf. Dalrymple et al. 1968). Saturation only appears in some of their lower parts, transformed to gullies by the following development.

Two of the detected shallow landslides are located in detachments of complex deformations and eight in independent positions. They are located at steep straight slopes (4 cases), heads of periodic spring areas (3 cases), detachment zones of large slope deformations ( 2 cases) and a local topographic escarpment (1 case). Most of them have a character of turf detachment - a dislocation along the lithologic boundary between the surface of stony deluvial sediments and the soil layer generated by the growing vegetation. A permanent spring was registered at only one place on a straight slope.

\section{Biotic properties of slope deformations}

The spatial distribution of the surface tendency to evolve hazardous slope processes, in the case of dwarf pine clearing in the particular areas of its occurrence, is closely related to the mentioned obvious link of both phenomena, abiotic and biotic, to the inclination conditions as the main determined regional geomorphological factor. The stands with low hazard are located in less inclined summit parts of the mountains with the minimum of slope deformations, where rather their influence on a wide range of other geomorphological processes of mainly periglacial character needs to be considered (Treml 2005, Treml and 
Křížek 2006, 2007). The stands with greater hazard, which are limited in space, are located in the upper parts of adjacent valley slopes with a higher frequency of deformations.

Active slope deformations affect, almost exclusively, surfaces covered in other kinds of vegetation; besides grass and isolated tree formations, these are also closed-canopy forest stands located below the dwarf pine layer (Roštínský 2012). It is highly probable that this is related to the predominant soil-protective network-arranged root structure of dwarf pine polycormons, the most abundant closed-canopy category of stand cover (cf. documented considerable reduction of the amount of destroyed surfaces without vegetation cover, in dependence on the increasing general cover of the area by dwarf pines in the high West Carpathian mountain ranges; Midriak 1983), as well as the prevailing stand layout with dominant isometric shapes of dwarf pine enclaves. This, in contrast to the zonal arrangement directed along the slope, reduces the potential of concentrated water runoff and thus the development of new linear forms (gullies, debris flows) in the slope parts that have been intact so far.

From the perspective of the defined types of slope deformations, the dwarf pine stands are thus of a higher significance for prevention or slowing down of the development of shallow small-area phenomena with a maximum thickness of several metres, especially shallow landslides with a character of turf detachments, and for the intensity of creeping of the superficial layer of deluvial sediments, mostly in the areas with fine-grained substrate. The current situation of the remedied area with the dense network of debris flows in Sněžná kotlina on Červená hora indicates that these stands may also have anti-destruction effect as they prevent origination of mentioned linear phenomena in relatively undamaged forestfree areas (cf. results of Treml 2005). Erosion preventive effects of the dwarf pine in the places that have already been cut by these forms, seem to be very limited due to the changed hydrological characteristics. Dwarf pine stands are not able to influence deeper movements of a block type within larger complex deformations, conditioned by both exogenous and endogenous factors (structure, young tectonic movements; e.g. Dikau et al. 1996).

\section{Proposals of dwarf pine stands management}

Out of the local reduction management measures taken for the dwarf pine stands since 1975 in a total area of several tens of hectares, we have to mention interventions conducted in the areas of cirques of Velká kotlina and Malá kotlina, with the purpose of freeing the avalanche paths within anemo-orographic systems (Bureš 1974a,b, Štykar and Buček 2012) and most recently on the summit of Kerpník with the purpose of freeing blown-out alpine biocoenoses. The complex proposal for dwarf pine clearing presented in the conclusion of a recent synthetic project $\mathrm{VaV} \mathrm{SM/6/70/05} \mathrm{(Hošek} \mathrm{et} \mathrm{al.} \mathrm{2007)} \mathrm{is} \mathrm{based} \mathrm{on} \mathrm{the} \mathrm{assumption}$ that the long-term aim is to reduce the abundance of this species in the Hrubý Jeseník Mountains as a whole. Therefore, the presented categorisation assumes clearing of dwarf pine stands in an area of 122.67 ha $(68.4 \%$ of all) in the short term and further 38.33 ha $(21.4 \%)$ in the medium term. "Temporarily" only $10.2 \%$ of the current stands above the tree line would be left. The authors of the previous project consider removal of nearly all dwarf pine stands, without taking into account possible environmental hazards (Maděra and Buček 2012).

The dwarf pine categorisation we propose with respect to hazardous slope processes considers the main geomorphological factors as one of the most important hazards, and captures the general tendency of the area to development of their forms in the entire area of the stands. The high variability of abiotic properties of particular parts of the study area gives reasons for amending and considering their more detailed characteristics and the level 
of hazard. This includes some smaller phenomena not contained within this study (e.g. minor fissures in the turf cover, shallow gullies) specific for each site even before potential project application for permission of another elimination intervention. The general management recommendations for particular defined categories of stands from the perspective of a substantial reduction or complete removal, often in a short term, can be summarised as follows:

Category 1: Dwarf pine reduction seems to be a negligible problem. It should not lead to a more extensive development of slope deformations. Despite this, an informative geomorpohological monitoring of slope deformations is recommended before a planned removal, with the purpose of comparing a possible evolution after its implementation.

Category 2: Dwarf pine reduction seems to be a potential problem. It could contribute to the development of slope deformations on smaller current sites or new sites. A detailed geomorphological survey indicating the existing slope disturbances (shallow landslides, turf detachments, erosion forms), establishment of structural relations (lithology, orientation of foliation planes, sediment grain size), survey of partial surface unevenness (scarps, undulating), spring or snow accumulation areas in relation to local forms of the surface, and potential areas with intensive creeping of superficial layer, should be conducted before a planned removal on the site and its surroundings. Its consequent evaluation, taking account of the information on the density and spatial structure of local stands, should determine the critical subareas excluded for a reason from the elimination measure.

Category 3: Dwarf pine reduction is a potential problem. It would contribute to the further evolution of existing slope deformations, especially in their upper detachment parts, which is not excluded even under the current situation. The changes of geomorphological and hydrological conditions in the landscape would be irreversible and are thus not desirable.

This categorisation, together with the four-stage categorisation of dwarf pine stands based on their effects on phenomena significant for nature conservation (Treml et al. 2007), should serve as a key material for decision making on the dwarf pine management on particular sites.

\section{CONCLUSIONS}

This new geomorphological research in the summit areas of the Hrubý Jeseník Mountains has documented the large extent of large-area and small-area slope deformations with variable abiotic (topography, lithology, rock structure, hydrology) and biotic (vegetation cover layout) properties including several types that have not been registered so far. Five main types have been distinguished; out of these, extensive complex slope deformations with numerous subforms in detachment parts, linear debris flows and local shallow landslides are in spatial and/or genetic relationships with the dwarf pine stands.

It was ascertained that dwarf pine stands do not have a great effect on the development of large relief forms; however, they have a significant reinforcement function, especially in the case of closed canopies, in prevention of smaller superficial deformations with a depth of several metres (shallow landslides, soil cover detachments, surface fissures, initial forms of debris flows) originating usually on slopes with higher inclinations. The provided threestage categorisation of dwarf pine stands, based on the tendency to an origination of hazardous slope processes, has defined $12 \%$ of stands on sites with the highest hazard of surface damage, especially on steep slopes; $13 \%$ on sites with middle hazard; and $75 \%$ on sites with a low hazard located usually in little inclined summit areas. 
The development evaluation or prediction of each site has to be approached individually, due to the high variability. A detailed geomorphological survey focusing on the indication of the current condition of slope deformations, out of the wide range of proposed abiotic and biotic aspects, should be conducted before a planned removal of dwarf pine stands; with the aim to define areas with the highest tendency to a further potential surface destruction. This would reduce the undesirable hazard of expansion of the current hazardous slope phenomena, or origination of new ones, as well as the related changes in the landscape, which are often irreversible. We hope the results of this study will serve as a suitable tool to find compromises between nature conservation and forest management, both for the decision making on the future of the dwarf pine stands, and for the general approach to human-inflicted permanent changes of the landscape in this region.

\section{ACKNOWLEDGEMENTS}

The contribution was produced with support of long-term conceptual development subvention of the research organizations RVO: 68145535, grant project of the State Enterprise Forests of the Czech Republic: Geobiocenózy horní hranice lesa a vliv porostů kleče na horskou krajinu Hrubého Jeseníku and the project Creation and development of multidisciplinary team on the basis of landscape (No. CZ.1.07/2.3.00/20.0004) with the financial contribution of EU and the state budget of the Czech Republic.

\section{REFERENCES}

Brunsden, D., (1993). Mass movement; the research frontier and beyond: a geomorphological approach. Geomorphology, 7: pp. 85-128.

Bureš, L., (1974a). Návrh projektu na experimentálni likvidaci části klečového porostu ve státni př́rodní rezervaci Malá kotlina. Správa CHKO Jeseníky, SÚPPOP, Praha.

Bureš, L., (1974b). Návrh projektu postupné likvidace kosodřeviny ve státní prírodni rezervaci Velká kotlina. Manuskript, Správa CHKO Jeseníky, SÚPPOP, Praha.

Businský, R., (1998). Agregát Pinus mugo v bývalém Československu: taxonomie, rozšíření, hybridní populace a ohrožení. Zprávy České Botanické Společnosti, 33: pp. 2952.

Chlupáč, I., Brzobohatý, R., Kovanda, J. \& Stráník, Z., (2002). Geologická minulost České republiky. Academia, Praha. 437 p.

Dalrymple, J.B., Blong, R.J. \& Conacher, A.J., (1968). A hypothetical nine-unit landsurface model. Zeitschrift für Geomorphologie, 12: pp. 60-76.

Demek, J., Mackovčin, P., et al. (2006). Zeměpisný lexikon ČR: Hory a nižiny. Agentura ochrany př́rody a krajiny ČR, Brno. 582 p.

Dikau, R., Brunsden, D., Schrott, L., Ibsen, M.-L., et al. (1996). Landslide recognition. Identification, movement and causes. Wiley, Chichester. $251 \mathrm{p}$.

Gába, Z., (1992). Mury pod Keprníkem v červenci 1991. Severní Morava, 64: pp. 43-50.

Hamerník, J., Musil, I., (2007). The Pinus mugo complex - its structuring and general overview of the used nomenclature. Journal of Forest Science, 53: pp. 253-266.

Horák, J., (1977). K problematice sudetských holí. In: J. Štursa (Ed.): Člověk a horská príroda ve XX. století, (p. 114-121). Špindlerův Mlýn. 
Hošek, E., (1973). Vývoj dosavadního hospodaření v nejvyšších polohách Jeseníků a jeho vliv na horní hranici lesa. Campanula, 4: pp. 69-81.

Hošek, J., Banaš, M., Černá, K., Hédl, R., Holuša, J., Kašák, J., Kočí, M., Kočvara, R., Kopalová, I., Křŕžek, M., Kuras, T., Kyncl, T., Majkus, Z., Novák, J., Petr, L., Potůčková, M., Šenfeldr, M., Souček, J., Treml, V., Wild, J., Zeidler, J. \& Zmrhalová, M., (2007). Vliv výsadeb borovice kleče (Pinus mugo) na biotopovou a druhovou diverzitu arkto-alpinské tundry ve Východních Sudetech (CHKO Jeseníky, NPR Králický Sněžník). Návrh managementu těchto porostů. Zpráva o řešení projektu VaV SM/6/70/05. Hořovice. 268 p.

Hrádek, M., (2010). Význam kleče pro udržení stability horských svahů v Hrubém Jeseníku. In: Campanula. Sbornik referátů z konference ke 40. výroči Chráněné krajinné oblasti Jeseniky, (p. 106-108). AOPK ČR - Správa CHKO Jeseníky, Jeseník.

Hrádek, M., Lacina, J., (2003). Destructional landforms arisen from extreme events in the Desná River valley and their vegetation. Moravian Geographical Reports, 11 (1): pp. 2-19.

Hrádek, M., Malik, I. \& Owczarek, P., (2006). Zapis aktywności spływów gruzowych na podstawie analyzy przyrostów rocznych drzew (Sudety Wschodnie). In: I. Smolová (Ed.): Geomorfologické výzkumy v roce 2006, (p. 65-69). Univerzita Palackého, Olomouc.

Křížek, M., (2007a). Periglacial landforms above the alpine timberline in the High Sudetes. In: J. Kalvoda, A. Goudie: Geomorphological variations, (p. 313-337). P3K, Prague.

Křížek, M., (2007b). Rychlé svahové procesy a jejich vztah k porostům borovice kleče. In: J. Hošek et al.: Vliv výsadeb borovice kleče (Pinus mugo) na biotopovou a druhovou diverzitu arkto-alpinské tundry ve Východnich Sudetech (CHKO Jeseniky, NPR Králický Sněžník). Návrh managementu těchto porostů. Zpráva o řešení projektu $\mathrm{VaV} \mathrm{SM/6/70/05,}$ (p. 208-220). Hořovice.

Jeník, J., (1961). Alpínská vegetace Krkonoš, Králického Sněžníku a Hrubého Jeseníku. Academia, Praha. 412 p.

Kuras, T., Beneš, J. \& Konvička, M., (2001). Behaviour and within-habitat distribution of adult Erebia sudetica sudetica, endemic of the Hruby Jesenik Mts., Czech Republic (Nymphalidae, Satyrinae). Nota Lepidopterologica, 24: pp. 69-83.

Midriak, R., (1983). Morfogenéza povrchu vysokých pohorí. VEDA, Bratislava.

Migoń, P., Hrádek, M. \& Parzóch, K., (2002). Extreme events in the Sudetes Mountains. Their long-term geomorphic impact and possible controlling factors. Studia Geomorphologica Carpatho-Balcanica, 36: pp. 29-49.

Nemčok, A., Pašek, J. \& Rybář, J., (1974). Dělení svahových pohybů. Sbornik geologických věd, Hydrogeologie, inženýrská geologie, 11: pp. 77-97.

Maděra, P., Buček, A., (2012). Úvod. In: M. Šenfeldr et al.: Kleč v horské krajině Hrubého Jeseníku. Geobiocenologické spisy, 16, (p. 7-8). CERM, Brno.

Opletal, M., et al. (1997). Geologická mapa ČR 1:50 000, list 14-24 Bělá pod Pradědem. Česká geologická služba, Praha.

Pilous, V., (1973, 1975, 1977). Strukturní mury v Krkonoších I, II, III. Opera Corcontica, 10: 15-69, 12: 7-50, 14: pp. 7-94.

Řehánek, T., (2003). Klimatická charakteristika CHKO. In: V. Kavalcová, K. Kavalec et al.: Chránéná území CHKO Jeseníky. Agentura ochrany př́rody a krajiny ČR a EkoCentrum Brno, Praha. 60 p.

Roštínský, P., (2010). Svahové deformace v oblasti Keprníku, Hrubý Jeseník. Zprávy o geologických výzkumech v roce 2009, pp. 20-23. 
Roštínský, P., (2012). Vztahy klečových porostů ke geomorfologickým procesům. In: M. Šenfeldr et al.: Kleč v horské krajině Hrubého Jeseníku. Geobiocenologické spisy, 16, (p. 15-69). CERM, Brno.

Rybář, J., (1999). Rozbor prř́čin zvýšeného výskytu svahových deformací v České republice v červenci 1997. Geotechnika, 1999 (2): pp. 7-14.

Rybář, J., et al. (1999). Hodnocení rizik nestability svahů v oblasti Valašské MeziřričíMikuli̊vka-Jablůnka-Malá Bystřice v okrese Vsetín. Ústav struktury a mechaniky hornin AV ČR, Praha. 21 p.

Sekyra, J., Kociánová, M., Štursová, H., Kalenská, J., Dvořák, I. \& Svoboda, M., (2002). Frost phenomena in relationship to mountain pine. Opera Corcontica, 39: pp. 69-114.

Šenfeldr, M., Maděra, P., Buček, A., Roštínský, P., Špinlerová, Z., Culek, M., Friedl, M., Štykar, J., Vavříček, D., Pecháček, J., Tippner, A. \& Sedláček, A., (2012). Kleč v horské krajině Hrubého Jeseníku. Geobiocenologické spisy, 16. CERM, Brno. 236 p.

Šilhán, K., (2008). Geomorfologie blokovobahennich proudi̊ v Moravskoslezských Beskydech. Disertační práce, Ostravská unverzita, Ostrava. 156 p.

Sokol, F., (1965). Vliv př́rodního prostředí a lidské činnosti na vznik svahových sesuvi̊ a dosavadni zkušenosti s jejich rekultivací v Hrubém Jeseniku. Kandidátská disertační práce, Mendelova zemědělská a lesnická univerzita, Brno. 370 p.

Štykar, J., Buček, A., (2012). Vývoj biotopů po odstranění kleče. In: M. Šenfeldr et al.: Kleč v horské krajině Hrubého Jeseníku. Geobiocenologické spisy, 16, (p. 202-214). CERM, Brno.

Tolasz, R., et al. (2007). Climate Atlas of Czechia. Czech Hydrometeorological Institute, Prague.

Tippner, A., (2012). Rozšśřřní klečových porostů. In: M. Šenfeldr et al.: Kleč v horské krajině Hrubého Jeseníku. Geobiocenologické spisy, 16, (p. 9-14). CERM, Brno.

Treml, V., (2005). Vliv kleče na geomorfologické procesy. In: J. Hošek et al.: Vliv výsadeb borovice kleče (Pinus mugo) na biotopovou a druhovou diverzitu arkto-alpinské tundry ve Východnich Sudetech (CHKO Jeseníky, NPR Králický Sněžník). Návrh managementu těchto porostů. Zpráva o řešení projektu VaV SM/6/70/05, (p. 54-67). Hořovice.

Treml, V., (2009). Lavinové dráhy. In: Hrnčiarová, T. et al.: Landscape atlas of the Czech Republic. Ministry of the Environment of the Czech Republic and Silva Taroucy Research Institute for Landscape and Ornamental Gardening, Praha-Průhonice.

Treml, V., Banaš, M., Kuras, T., Zeidler, M. \& Kočvara, R., (2007). Návrh managementových opatření porostů borovice kleče (Pinus mugo) v Hrubém Jeseníku a Králickém Sněžníku. In: J. Hošek et al.: Vliv výsadeb borovice kleče (Pinus mugo) na biotopovou a druhovou diverzitu arkto-alpinské tundry ve Východnich Sudetech (CHKO Jeseníky, NPR Králický Sněžník). Návrh managementu těchto porostů. Zpráva o řešení projektu VaV SM/6/70/05, (pp. 221-268). Hořovice.

Treml, V., Křížek, M., (2006). Vliv borovice kleče (Pinus mugo) na strukturní půdy v Hrubém Jeseníku a Králickém Sněžníku. In: J. Hošek et al.: Vliv výsadeb borovice kleče (Pinus mugo) na biotopovou a druhovou diverzitu arkto-alpinské tundry ve Východnich Sudetech (CHKO Jeseníky, NPR Králický Sněžník). Návrh managementu těchto porostů. Zpráva o řešení projektu VaV SM/6/70/05, (pp. 69-83). Hořovice.

Treml, V., Křížek, M., (2007). Vliv borovice kleče (Pinus mugo) na půdní kopečky (thufury) v Hrubém Jeseníku. In: J. Hošek et al.: Vliv výsadeb borovice kleče (Pinus mugo) 
na biotopovou a druhovou diverzitu arkto-alpinské tundry ve Východnich Sudetech (CHKO Jeseniky, NPR Králický Sněžník). Návrh managementu těchto porostü. Zpráva o řešení projektu VaV SM/6/70/05, (pp. 141-152). Hořovice.

Treml, V., Wild, J., Chuman, T. \& Potůčková, M., (2010). Assesing the change in cover of non-indigenous dwarf pine using aerial photographs, a case study from the Hrubý Jeseník Mountains, the Sudetes. Journal of Landscape Ecology, 4: pp. 90-104.

Záruba, Q., Mencl, V., (1969). Sesuvy a zabezpečování svahů. Academia, Praha. 224 p.

Zeidler, M., Banaš, M., Duchoslav, M. \& Lešková, M., (2010). Vliv vysazených klečových porostů na alpínskou vegetaci v Hrubém Jeseníku. Př́roda, 29: pp. 37-50.

Zeidler, M., Duchoslav, M., Banaš, M. \& Lešková, M., (2012). Impacts of introduced dwarf pine (Pinus mugo) on the diversity and composition of alpine vegetation. Community Ecology, 13 (2): pp. 213-220.

Zvejška, F., (1947). O vzniku horských strží v povodí Hučivé Desné. Časopis Zemského Muzea v Brně, 31: pp. 3-15. 